\title{
"When does it stop being peanut butter?": FDA food standards of identity, Ruth Desmond, and the shifting politics of consumer activism, 1960s- 1970s.
}

\section{Citation}

Boyce, Angie M. 2016. "When does it stop being peanut butter?": FDA food standards of identity, Ruth Desmond, and the shifting politics of consumer activism, 1960s-1970s. Technology and Culture 57, no. 1:54-79. doi:0.1353/tech.2016.0016.

\section{Published Version}

10.1353/tech.2016.0016

\section{Permanent link}

http://nrs.harvard.edu/urn-3:HUL.InstRepos:27022907

\section{Terms of Use}

This article was downloaded from Harvard University's DASH repository, and is made available under the terms and conditions applicable to Other Posted Material, as set forth at http:// nrs.harvard.edu/urn-3:HUL.InstRepos:dash.current.terms-of-use\#LAA

\section{Share Your Story}

The Harvard community has made this article openly available.

Please share how this access benefits you. Submit a story.

\section{Accessibility}




\title{
"When Does It Stop Being Peanut Butter?"
}

\author{
FDA Food Standards of Identity, Ruth Desmond, and \\ the Shifting Politics of Consumer Activism, 1960s-1970s
}

ANGIE M. BOYCE

\begin{abstract}
This article uses a historical controversy over the U.S. Food and Drug Administration's standard of identity for peanut butter as a site for investigating three topics of high importance for historians of technology, consumption, and food activism: how new industrial food-processing technologies have become regulatory problems; how government, industry, and consumer actors negotiate standards development; and how laypeople try to shape technological artifacts in spaces dominated by experts. It examines the trajectory of consumer activist Ruth Desmond, co-founder of the organization the Federation of Homemakers. By following Desmond's evolving strategies, the article shows how the broader currents of the 1960s-70s consumer movement played out in a particular case. Initially Desmond used a traditional style that heavily emphasized her gendered identity, working within a grassroots organization to promote legislative and regulatory reforms. Later, she moved to a more modern advocacy approach, using adversarial legal methods to fight for consumer protections.
\end{abstract}

In 1959, the U.S. Food and Drug Administration (FDA) published a proposed standard of identity, or regulatory definition, for peanut butter. It was not able to finalize the standard, however, until 1970, after a federal district court of appeals dismissed legal challenges from the peanut butter industry. ${ }^{1}$ The case stopped just shy of the Supreme Court. A regulatory

Angie M. Boyce is a Robert Wood Johnson Foundation Health \& Society Scholar at the Harvard T. H. Chan School of Public Health, and an affiliate of the Center for Population and Development Studies. She earned her Ph.D. in Science \& Technology Studies at Cornell University in 2014. She thanks Katherine Darling, Stephen Hilgartner, Ronald Kline, Michael Lynch, Nicole Nelson, Trevor Pinch, Hannah Rogers, and the four anonymous reviewers for their helpful feedback. This article benefited greatly from Barbara Hahn's editorial hand. The research was supported by the National Science Foundation Graduate Research Fellowship Program.

(C)2016 by the Society for the History of Technology. All rights reserved. 0040-165X/16/5701-0003/54-79

1. Corn Products Company v. Department of Health, Education and Welfare, Food and Drug Administration, and Derby Foods, Inc. v. Food \& Drug Administration, U.S. Department of Health, Education, and Welfare, 427 F.2d 511 (3rd Cir. 1970). 
hearing to settle controversy around the peanut butter standard spanned more than five months in the fall of 1965 and spring of $1966 .{ }^{2}$ Years after the standard was finalized, President Jimmy Carter criticized it in a 1979 press conference, scoffing that "it should not have taken 12 years and a hearing record of over 100,000 pages for the FDA to decide what percentage of peanuts there ought to be in peanut butter." ${ }^{3}$ Why did the regulatory definition of peanut butter create such a storm?

Benjamin Gutterman, the FDA assistant director of the Bureau of Foods, summed up the key question of the debate as "when does it stop being peanut butter?" According to Gutterman, that question represented a battle line between the U.S. government and the peanut butter industry over a standard for peanut butter identity that defined a mandatory percentage of peanuts and threshold for optional ingredients such as chemical additives, emulsifiers, stabilizers, and hydrogenated oils. He contended that the industry would have argued for a lower percentage than the government no matter what the proposed threshold was. Gutterman stated that the FDA did not necessarily argue that a more processed peanut butter with lower percentages of peanuts and higher percentages of optional ingredients was a "bad product." Instead, he stated, consumers did not "expect" such a product to be named "peanut butter," and it was the FDA's responsibility to create food standards in line with consumer understanding of the product. ${ }^{4}$

Carter's characterization of the controversy pinned the blame on FDA decision-making, and Gutterman's emphasized a battle between the government and industry. However, a closer examination reveals that another player negotiated a significant role in the hearing. A consumer representative attracted national media attention to the peanut butter standardRuth Desmond, the co-founder of a consumer organization called the Federation of Homemakers. Desmond would be memorialized as the "peanut butter grandmother" for her activist work around the standard-of-identity hearing; she constructed her consumer identity as a "well-informed housewife," an ordinary person who, "without being the least bit expert," desired access to expert debates about possible risks and hazards of augmentations such as chemical additives, pesticide residues, and preservatives. During the hearing, she argued that "old-fashioned" peanut butter made of "just peanuts and salt" was being unfairly supplanted in the marketplace by a "new," "technological" peanut butter, to the detriment of consumer health. ${ }^{5}$

The debate about the peanut butter standard of identity, and Desmond's role in it in particular, is a topic not only relevant to the broader

2. "Definitions and Standards of Identity for Peanut Butter, Docket no. 76," Boxes $1-11$, in NARA.

3. Jimmy Carter, "The President's News Conference."

4. As quoted in Joseph C. Goulden, The Superlawyers, 187-88.

5. 8 February 1966, 6162, in NARA. 
JANUARY

2016

VOL. 57

history of consumption, but features several elements of particular interest to historians of technology. Peanut butter provides a historical window into the industrialization of the U.S. food supply, especially the ways in which new industrial food-processing technologies became regulatory problems. Indeed, as FDA historian Suzanne Junod argues, the peanut butter controversy played a particular role in the FDA's move away from the standard-of-identity mechanism. After the dispute, the FDA changed its focus to developing nutrition and labeling standards. ${ }^{6}$ The peanut butter debate shows how involved actors struggled with a core tension related to standards: the relationship between government and private industry in standards development. ${ }^{7}$

Furthermore, this case is relevant to another topic of interest in both the history of technology and the history of consumer activism: how consumers try to shape technological artifacts. Attention to Desmond's activist work helps illuminate how an enterprising consumer pried open a standards-setting procedure to affect the artifact, strategically navigating her way among legal, technical, and regulatory experts. ${ }^{8}$ That the hearing was such an extended proceeding offers an opportunity to examine Desmond's rhetorical maneuverings and her interactions with experts in a detailed fashion.

This article follows Desmond's work as a consumer activist before, during, and after the peanut butter hearing, chronicling how, over time, her strategies shifted. At first, Desmond used a style more in keeping with traditional consumer activism, working within a grassroots organization to promote legislative and regulatory reforms, and emphasizing her gendered social identity. After the peanut butter hearing, Desmond and her organization shifted to a more modern consumer advocacy approach, affiliating with Ralph Nader and using adversarial legal methods to fight for consumer protections, representing a more generic version of the consumer. Following her trajectory enables us to see how the broader currents of the 1960s-70s consumer movement played out in a particular case.

6. Suzanne Junod, "The Rise and Fall of Federal Food Standards."

7. For a review of the history of standards literature, see Andrew L. Russell, "Standardization in History." See also Lawrence Busch, Standards; Martha Lampland and Susan Leigh Star, eds., Standards and Their Stories; and Stefan Timmermans and Steven Epstein, "A World of Standards but Not a Standard World."

8. For key pieces on tactics laypersons use to interact with experts, see Steven Epstein, "The Construction of Lay Expertise" and Impure Science; Brian Wynne, "Misunderstood Misunderstanding"; Shobita Parthasarathy, "Breaking the Expertise Barrier"; and Wiebe Bijker and Karin Bijsterveld, "Women Walking through Plans." 


\section{From Ordinary Consumer to Consumer Activist}

Desmond started her consumer activist work in the late 1950s, when her husband was diagnosed with bladder cancer while in his forties. ${ }^{9}$ As an upper-middle-class housewife, mother, and grandmother residing in Arlington, Virginia, she emphasized her ordinariness in a press interview, claiming that she had "never been a maverick or a leader." ${ }^{10}$ Because of her husband's illness, Desmond sought more information about cancer, and began to conduct library research on the disease. Through her reading, she discovered that pesticide residues and chemical additives in food were thought to be a potential cause. Angered by her findings, she placed a phone call to the FDA, which responded by inviting her to attend congressional hearings on food additives.

Attending these hearings was a politicizing experience driving Desmond to join with others and create the Federation of Homemakers, because it made the women realize "how little information of vital interest to homemakers regarding the testimony of recognized scientists was published in newspapers and magazines." Desmond invoked "fairness" to argue that the "homemakers of the Country" should be able to have a say in "food handling and treatment," and about whether they would be willing to "take certain risks with the health of their families." 11 After the food additive hearings, the group's founders began to publish a quarterly newsletter, write letters to government officials, and attend and testify at a broad array of regulatory hearings in Washington, ranging from appropriations to product safety.

Desmond pinned blame for the housewife's uninformed status on food advertising, food industry public relations departments, lack of coverage about health risks in newspapers, and inadequate product labels. She complained that she and other Federation officers had to attend regulatory hearings in person, or read records of the proceedings in agency reading rooms to get access to information. The kind of information discussed in hearings was particularly important because it revealed expert debates about possible health risks, a huge area of importance and interest to consumers, but unavailable in other venues.

A profile of Desmond in Prevention magazine scoffed at the government's limited means of disseminating regulatory information to consumers. ${ }^{12}$ "The American housewife," it argued, was "not complacent" or "unconcerned," but "uninformed of the risks and hazards." This was the

9. 8 February 1966,6214 , in NARA.

10. Carole Sugarman, "Veteran of the Peanut Butter War."

11. "Statement of the Federation of Homemakers before the Subcommittee on Health and Safety, House Interstate and Foreign Commerce Committee," testimony (7 August 1962), Box 2, Folder 18, in Delaney Papers.

12. "Peanut Butter Grandma, the Terror of Washington," 1971, Prevention, Box 2, Folder 18, in Delaney Papers. 
JANUARY

2016

VOL. 57

"only reason she is not heard from in thunderous numbers when legislation is pending." Desmond saw hearings as one of her key targets, later reflecting on her role as a self-described "congressional hearing chaser." ${ }^{13} \mathrm{By}$ attending hearings and participating as an ordinary consumer, she could "speak for all consumers who are interested in standards, food standards, and have not been able to come personally." 14

\section{The Housewife's Technology Problem}

Desmond's success as a consumer activist must be attributed in part to the fact that she personified an idealized figure central to the government's rhetoric on the problem of consumption during the 1960s, first articulated during John F. Kennedy's 1962 special message to Congress. ${ }^{15}$ President Kennedy stated that the consumer had four rights-to be safe, to be informed, to choose, and to be heard-and also argued that the "march of technology" created both "opportunities" and "difficulties" for one consumer in particular-the housewife. While the housewife was "called upon" to act as an "amateur electrician, mechanic, chemist, toxicologist, dietitian, and mathematician," Kennedy pointed out that she was not properly "furnished" with the information she needed to do those jobs. He articulated a triadic frame for the problem of consumption: the housewife as vulnerable consumer, the march of technology as the cause of consumer vulnerability, and information as the key to managing vulnerability. This speech shaped the FDA's regulatory frame. FDA commissioner George Larrick drew on the speech specifically and called for industry and government to work together to "do the job the individual housewife would do if she were preparing a product in her own kitchen," given that the "evolution of technology" required increased "safeguards" for the end consumer. ${ }^{16}$

In the same year as Kennedy's address, Desmond testified before a House of Representatives subcommittee meeting on health and safety and "endorsed" Kennedy's remarks, "especially" the right to be informed and the right to be heard. ${ }^{17}$ Desmond used Kennedy's triad, though it created both opportunities and constraints for her consumer activism. She could personify his key rhetorical figure of the "housewife" because of her social identity, but she also confronted what historian Thomas Stapleford calls a "schizophrenic" discourse around the housewife as an expert on con-

13. Elissa Vanaver, "The Peanut Butter Grandma."

14. 8 November 1965,741 , in NARA.

15. John F. Kennedy, "Special Message to the Congress on Protecting the Consumer Interest."

16. George Larrick, "The FDA and Consumer Protection."

17. "Statement of the Federation of Homemakers before the Subcommittee on Health and Safety, House Interstate and Foreign Commerce Committee," testimony (7 August 1962), Box 2, Folder 18, in Delaney Papers. 
sumption; sometimes she would be framed as a rational manager of the home, while at other times she was framed as a "confused woman desperately in need of expert guidance." 18

Though Kennedy's vision gained prominence in the 1960s, its appeal lay in its resonance with enduring frameworks for consumption in U.S. political culture. ${ }^{19}$ Ralph Nader would hail Desmond as the "only remaining 'heiress' to a tradition, a tradition of home-economics activism that started at the turn of the century with women such as Carry Nation."20 Indeed, Desmond herself made it very clear in her rhetoric that she was drawing from a long-standing legacy of women consumer activists fighting for pure foods and drugs. The Federation described itself as "dedicated to furthering the philosophy of Dr. Harvey W. Wiley, Father of our first Pure Food and Drug Act." ${ }^{21}$ Wiley had been joined by a broad coalition of crusading women's groups, including the Woman's Christian Temperance Union and General Federation of Women's Clubs, which worked together to win passage of the 1906 act. $^{22}$ These groups characterized women as "homekeepers of the land" with a home protectionist ethic, and mothers fighting to protect their children and communities, applying their homemaking skills to cleaning up the public arena. ${ }^{23}$ This coalition remained important in subsequent regulatory reform efforts, supporting the passage of the Food, Drug, and Cosmetic Act (FDCA) in 1938. ${ }^{24}$

The "well-informed" portion of Desmond's housewife identity drew much of its historical resonance from home economics. Historian Carolyn Goldstein argues that in the early-to-mid-twentieth century, home economists were central actors who created a framework of "rational consumption" that sought to teach women how to buy goods and manage their budgets as the home and its wares became increasingly complex. ${ }^{25}$ "Rational consumption" framed the problem of consumption as a lack of information. Home economists became important mediators between industry, government, and consumers, shaping the development of many food standards. What gave them credibility and professional standing was a dual identity as both experts on consumption and representatives of ordinary consumers.

18. See Thomas Stapleford, "'Housewife vs. Economist."

19. Lawrence Glickman, Buying Power, 257.

20. Nader, as quoted in Sugarman, "Veteran of the Peanut Butter War," D1.

21. "A Brief History [Federation of Homemakers]," 5 March 1979, in WSU.

22. Jeffrey Haydu, "Frame Brokerage in the Pure Food Movement."

23. Lorine Swainston Goodwin, The Pure Food, Drink, and Drug Crusaders, 87-89. For other discussions of the historical role of women in consumer movements, see Lizabeth Cohen, A Consumers' Republic; Meg Jacobs, Pocketbook Politics; Michele Micheletti, "Why More Women?"; Kathryn Kish Sklar, “The Consumers' White Label Campaign"; Erna Melanie DuPuis, Nature's Perfect Food; and Carolyn de la Peña, Empty Pleasures.

24. Daniel Carpenter, Reputation and Power. Life."

25. Carolyn Goldstein, Creating Consumers. See also Amy Sue Bix, "Equipped for 
Yet as Desmond began her activist work in the 1960s, home economists were losing their status as experts on consumption. The male-dominated fields of food engineering, nutrition, and formal marketing began to marginalize the expertise of home economists and threaten their standing in government and industry. As Goldstein charts, home economists played

JANUARY

2016

VOL. 57 a diminished role in the 1960s-70s consumer movement, due to tensions between reform and business divisions of the profession; for example, members of the American Home Economics Association (AHEA) fought over whether to use their organization to lobby for legislative change. ${ }^{26}$

Although Desmond took up home economists' formulation of the problem of consumption as lack of information, and saw the AHEA as an ally, her construct of the well-informed housewife as a consumer representative shifted the relationships between ordinary consumers, experts, and the government. Expert groups like home economists would no longer speak directly for ordinary consumers to the government, but would produce and share information about possible risks and hazards to edify them. That way, ordinary consumers could become well-informed, and would thus be both better prepared and entitled to have more direct involvement in policymaking arenas.

\section{Constructing a Product Identified as "Peanut Butter"}

Before delving further into Desmond's trajectory as a consumer activist, I will first briefly describe the history of peanut butter and how it became associated with the standard-of-identity mechanism. In some ways, peanut butter was a food fitting Desmond's gendered and aged consumer identity, giving her special symbolic authority to have a say in what its composition should be. The food had developed a special association with children, which had intensified over the course of the twentieth century due to peanut butter manufacturers' targeted advertising and the growing use of the food in children's brown-bag lunches, as well as in the U.S. school lunch program. It was also associated with sick, elderly, and poor populations, since it had been created by John Harvey Kellogg in the late nineteenth century to feed those of his sanitarium patients who had difficulty chewing peanuts. During World War I it emerged as a cheaper protein substitute for meat. ${ }^{27}$

However, in other ways, peanut butter was an imperfect fit for Desmond's goal to raise concerns about possible risks from food additives, since no specific health scare was attached to the peanut butter standard of identity. Even more importantly, in the consumer mind, peanut butter was an elusive, contested thing, as the standard-of-identity debate itself dem-

26. Goldstein, Creating Consumers, 301.

27. Jon Krampner, Creamy \& Crunchy; Andrew Smith, Peanuts; and Kara Newman, "Historical Overview," 220. 
onstrates. While Desmond claimed to speak for other consumers to decry the usurpation of "old-fashioned" peanut butter in favor of a more processed variety in the 1960 s, by the 1920 s peanut butter had already been converted from a faddish health food popularized by vegetarians to a massmarketed, branded, and industrialized national product. ${ }^{28}$ All participants in the hearing, including Desmond, constructed their own versions of what peanut butter was and what it symbolized, to try to shape the food's regulatory definition and determine who best represented the consumer voice.

Peanut butter had been on the FDA's radar screen since 1940, when a manufacturer asked the agency if it could add glycerin to the product to prevent oil separation. ${ }^{29}$ However, the agency did not pursue a standard of identity for the product until nearly two decades later, as we shall see. When Congress passed the Food, Drug, and Cosmetic Act (FDCA) in 1938, one power that it granted the FDA was to develop food standards of identity, or definitions prescribing regulatory "recipes" for the production of individual foods. ${ }^{30}$ The FDCA's description of the standard of identity was sparse, but had a few key elements. Standards of identity for foods were supposed to promote the broader FDCA standard of "honesty and fair dealing in the interest of consumers." Foods would be standardized under their "common or usual" names. This choice prioritized everyday staples as targets as they would impact the largest number of consumers. Food itself was subdivided into two partitions-mandatory and optional ingredients - creating thresholds delimiting the types and amounts of materials used to manufacture food. ${ }^{31}$

The underlying philosophy of the FDA framework was Congress's initial conception of the standard of identity as a "recipe," a concept initially supported by the agency because it believed that recipes would make regulatory enforcement easier, evoking the simple, straightforward quality of a recipe consisting of a list of ingredients and instructions for combining them. ${ }^{32}$ Standards of identity would be the regulatory mechanism to ensure foods met the "time honored standards employed by housewives and reputable manufacturers." 33 Cookbooks were often used to formulate initial standards in this process. ${ }^{34}$ Through the "simple" recipe-based approach, standards of identity were initially developed for many common, "traditional" foods in the 1940s-50s, for example, tomato products, jams and jellies, chocolate, flour, and butter.

28. Smith, Peanuts, 37-44.

29. Junod, "The Rise and Fall of Federal Food Standards in the United States," 46.

30. Richard A Merrill and Earl M. Collier Jr., "Like Mother Used to Make."

31. Food, Drug, and Cosmetic Act of 1938.

32. Junod, "The Rise and Fall of Federal Food Standards," 46.

33. H.R. 2139, 75th Cong., 3d Sess. 5 (1938), as quoted in Merrill and Collier, Like Mother Used to Make, 567.

34. Junod, "The Rise and Fall of Federal Food Standards," 43. 
The standard-of-identity recipe approach was facilitated by the routine use of two mechanisms from the 1946 Administrative Procedure Act (APA). The act stipulated that all regulatory agencies, including the FDA, would develop regulations through notice-and-comment rulemaking involving correspondence between "interested parties" and the government,

JANUARY

2016

VOL. 57 and also institute a hearing procedure where opposing parties would present evidence to the judge, or hearing examiner. ${ }^{35}$ Standard-of-identity hearings were formal and legalistic, involving testimony and cross- and direct examination, and the voir dire (trial-within-a-trial) procedure of evaluating the credibility of expert witnesses and the admissibility of every piece of evidence admitted into the record.

However, as traditional foods began to fundamentally change in character with the increasing use of chemical additives and complex processing techniques, the simple recipe approach to food standardization became controversial, first with chemical additives in white bread, and later with processed orange juice. ${ }^{36}$ In October 1958, FDA commissioner George Larrick addressed the Peanut Butter Manufacturers Association (PBMA), to publicly inform the industry that the agency was considering issuing a standard for peanut butter. ${ }^{37}$

What triggered the agency's concern was that a "product identified as 'peanut butter" had recently entered the marketplace, and used an unprecedentedly high percentage of hydrogenated cottonseed and soybean oil and artificial flavor, not identified on the label as required by the law. The product in question was Jif, which Procter \& Gamble (P\&G) had introduced that year to compete with what had become the two most popular brands of peanut butter, Skippy and Peter Pan. Larrick worried that P\&G's new formulation would "readily mislead the consumer," given that for a "generation" peanut butter had retained a "relatively uniform composition" of ground peanuts and a minimum amount of additional ingredients. ${ }^{38}$

Before and after Larrick's address, the FDA had been speaking informally with the peanut butter industry about its positions on a standard of identity. ${ }^{39}$ Initially, the agency had some hesitations about moving forward with the peanut butter standard. Preparing evidence for and conducting a hearing would be time-consuming and expensive for the FDA, given that it was already embroiled in the "time-consuming problems" of ice cream, tuna, mozzarella, artificially sweetened jams and jellies, and orange juice. Criticism of the FDA's food standardization program was growing within the food industry, as manufacturers saw it as discouraging to research and

35. Richard Stewart, "Vermont Yankee."

36. Junod, "The Rise and Fall of Federal Food Standards," 44-46. See also Suzanne Junod, "Chemicals and Controversy," and Alissa Hamilton, Squeezed.

37. George Larrick, "Behind the Peanut Butter Label," Box 28, in NARA.

38. Memorandum of Interview, “Jif” Peanut Butter, 23 July 1958, Box 29, in NARA.

39. Memorandum, "Proposed Identity Standard for Peanut Butter," 10 March 1959, Box 28, in NARA. 
innovation for product improvement. For example, one industry lawyer wrote, "The admirable goal of consumer protection against fraud has been used by the FDA to strait-jacket the development of food technology." 40

Yet despite growing criticism, the FDA did decide to pursue a standard of identity for peanut butter. Legal scholars argue that the FDA's decision was driven by P\&G's "novel use of hydrogenation of oils." 41 The FDA wanted P\&G to call hydrogenated cottonseed or soybean oil "Crisco base" on the label, but the company objected. ${ }^{42}$ As a result of its investigation, the FDA decided that Jif was "not entitled to the name 'peanut butter," due to its unprecedentedly low percentage of peanuts (75 percent) and high use of non-peanut hydrogenated oils and artificial flavor. ${ }^{43}$

The first peanut butter standard, published in March 1959, proposed a 95 percent peanut threshold and limited optional ingredients, but subsequent versions lowered the threshold to 90 percent and allowed for more diverse optional ingredients. ${ }^{44}$ From November 1964 to May 1965, the agency received more than 1,900 comments from "interested persons." 45 An FDA analysis of these comments laid out the various positions of industry actors and consumers. For example, the PBMA proposed an 87 percent peanut threshold, but the FDA found that the two biggest manufacturers, Corn Products Company (maker of Skippy) and Derby Foods (maker of Peter Pan), were the strongest advocates of the 87 percent figure. The FDA therefore argued that 'PBMA's 'representation' means very little and that the correspondence from peanut butter manufacturers should be taken on its own merits." Showing that manufacturers held different positions would help the FDA pursue a higher standard. ${ }^{46}$

The FDA also concluded that consumers desired a 95 percent threshold, with a 90 percent minimum. Three of the consumer comments were formal letters from the Federation of Homemakers (authored by Desmond), though the FDA noted that over 200 other consumers who submitted comments might have been influenced by the Federation. The first letter, from 1959, supported the 95 percent mandatory peanut threshold, and noted that the AHEA also supported this standard. The second letter, from November 1964, protested the raising of the optional ingredients threshold to 10 percent and posed questions about possible risks from

40. Esther O. Kegan, "A Unique Food or an 'Imitation'?"

41. Merrill and Collier, Like Mother Used to Make, 602.

42. Memorandum of Interview, "Jif" Peanut Butter, 23 July 1958, Box 29, in NARA.

43. FDA Memo from Bureau of Field Administration to Chiefs of Baltimore, Buffalo, and Chicago Districts on "Jif" Peanut Butter, Box 28, in NARA.

44. 24 Federal Register 5391 (1959), 26 Federal Register 11209 (1961), 29 Federal Register 15173 (1964).

45. Briefing Memorandum, "Peanut Butter identity standard," 24 May 1965, Box 47, in NARA.

46. RE Newberry, "Conclusions based on comments made by the peanut butter manufacturers, consumers, and state organizations," 28 May 1965, Box 47, in NARA. 
chemical additives. ${ }^{47}$ In January of 1965, after Desmond read other interested-party comments, she sent another comment calling for a public hearing to "air and resolve these differences." 48 Near the end of the comment period for the July 1965 standard, the agency had finally decided that a hearing was "inevitable." 49

JANUARY

2016

VOL. 57

\section{An Active Role for an Ordinary Consumer}

While Desmond had previously participated in standards development procedures as a submitter of comments and participant in congressional and regulatory hearings, she had an even more active role in her sights for the peanut butter hearing. It is likely that she pursued this because in the 1961 orange juice hearings, her organization had been able to play only a limited part. ${ }^{50}$

Before the FDA began the peanut butter hearing, it held two pre-hearing conferences, on 4 and 20 October 1965, to determine which specific issues would be discussed. A newsletter the Federation later sent to its members described why Desmond wanted such an active role. ${ }^{51}$ Though the pre-hearings were an "ordeal" to navigate without legal advice, Federation officers felt it would be a "tragedy" if the "voice of the consumer was stilled merely because it was impossible to obtain expert counsel." The group criticized the "legal red tape and procedures" that would prevent a consumer organization from "speaking for its membership." Fortunately for the Federation, the FDA allowed the group's officers to "participate actively ... even to cross-examining witnesses and objecting to certain questions and answers." Desmond took the lead role as a consumer counsel speaking for herself, her organization, and, by extension, all consumers. In doing so she made herself into a spokesperson, a tactic more in keeping with new consumer-advocacy methods. Why did the FDA allow Desmond to take on such a function? She had attracted national media attention with her participation, so of course the agency's public image was at stake.

To the press, Larrick expressed "great concern" over the "very limited extent of consumer participation in these [standard of identity] hearings," and emphasized that Desmond and the Federation were "very much welcomed." ${ }^{2}$ Later, an agency official reflected that during this time, the agency knew that it needed a consumer constituency to help it administer

47. Federation of Homemakers, "Re: Proposed Modification of Standard of Identity for Peanut Butter," 27 November 1964, Box 47, in NARA.

48. Federation of Homemakers, "Re: FDA's Modified Standard of Identity for Peanut Butter," 22 January 1965, Box 47, in NARA.

49. "Subject: Peanut Butter," undated, Box 11, in NARA.

50. Alissa Hamilton, Squeezed.

51. Federation of Homemakers, "A Capsule Account of FDA's Peanut Butter Hearing," Box 4 , in NARA.

52. Katie Dibell, "Housewives Lobby through Federation of Homemakers." 
its regulations, to counterbalance industry's ability to lobby Congress or the president. At that time, he said, "there was not a well-organized consumer movement, such as there is today. There was Ruth Desmond."53

Portraying herself as an underdog was an important part of Desmond's strategy to enact a critique of the standards process. For example, during the hearing, she thanked the experts in the room for allowing her to represent consumers without legal counsel, but emphasized that it was "an unequal contest with almost unsurmountable difficulties." ${ }^{54}$ Her underdog status, gendered consumer identity, and battle for a popular food made her a compelling figure for the media to profile, and helped thrust the peanut butter standard into the national limelight. The press painted a homespun picture of the "peanut butter grandmother" and the seventy-five crusading homemakers from her organization attending the hearing with the Washington bureaucrats and industry lawyers, taking on the "big boys in [the] food industry" to fight for old-fashioned peanut butter. ${ }^{55}$ Desmond made clear that the 95 percent mandatory peanut threshold was a strategic target, joking: "We're going to hold out for $95 \ldots$ this way we figure that we ought to get 90 to $10 \ldots$ it's all womanly reasoning." 56

This folksy and highly gendered media persona did play off of Desmond's genuine characteristics to garner publicity for the peanut butter standard, but it belied her educational background and strategic acumen. What the press did not mention was that Desmond's father had been an attorney, that she had worked briefly as a legal secretary, and had recently taken college courses at American University in psychology, public speaking, and government, though she had not continued her coursework because of her husband's health problem. ${ }^{57}$ Though clearly an ordinary consumer, it was not as if she had no qualifications for the role she undertook. Indeed, as an FDA official later recounted, Desmond "had a knack of getting in places where they [professional consumer advocates] couldn't get because of her style. ... She was smart as a whip, but she . . came across like she didn't know." 58

I call Desmond's "style" polite pointedness, which helped her navigate the hearings. She would routinely thank and compliment witnesses for their testimony, reflecting social norms of proper gender conduct and interaction between an ordinary housewife and predominantly male experts. Politeness helped portray Desmond as a sincere, well-meaning, and concerned homekeeper of the land. But her politeness was counterbalanced by an at times pointed and even blunt approach, especially when dealing with

53. James Harvey Young and Robert Porter, Rankin interview.

54. 13 December 1965, 3120-21, in NARA.

55. Associated Press, "Crunch Said Yet to Come in Battle on Peanut Butter"; Carole Sugarman, "Housewife Battles Big Boys in Food Industry."

56. Associated Press, "Women Battle over Peanuts."

57. 8 February 1966, 6213-15, in NARA.

58. Suzanne W. Junod and Robert A. Tucker, Grant interview. 
JANUARY

2016

VOL. 57

the issue of expert conflict of interest. To some degree, this more aggressive manner was afforded by Desmond's aged status as a grandmother requiring some social deference.

Polite pointedness helped Desmond navigate the hearings and insert a number of arguments and critiques into the record that otherwise might not have been made by other more expert parties in attendance. But while her ordinary consumer style gave her some advantages, it also left her with significant disadvantages-always at stake were whether or not she was seen as comprehending or "confused," and whether her arguments were deemed relevant or hearsay.

\section{Peanut Butter "Should Not Be Made Complicated"}

It was not predetermined that Desmond would take such an active role in the hearings. During the pre-hearings, Thomas Austern, an industry lawyer representing P\&G, tried to circumscribe Desmond's participation, arguing that since the hearing was to be "highly technical," involving extensive discussions on topics like hydrogenation, oil chemistry, and statistical sampling, the hearing examiner should consider "separating the technical aspects from the consumer aspects." At first, hearing examiner William Brennan responded by saying that this was "very possible," but Desmond countered quickly, contending that the Federation "would object very strenuously to this." To convince Brennan, Desmond argued that the Federation wanted to be present to hear all of the technical aspects, since her group had been following the peanut butter standard since 1959 and lobbying Congress for a hearing. She felt it would be "unfair" to be excluded from the technical aspects. She called peanut butter a special food because it was "a product that everyone understands," one consumed primarily by children that "should not be made complicated." 59

Desmond conceded that perhaps other foods could be manufactured in a complicated (i.e. industrially processed) manner, but argued that all consumers understood peanut butter to be a simple food that should not be made complicated through processing and the addition of chemical additives, especially when consumers would not be aware of these changes because they were not represented on the label. At the end of the pre-hearings, Brennan assured Desmond that she would not be "precluded" from the technical aspects of the hearing, and that her "keen interests as a consumer" were recognized. ${ }^{60}$

During the hearings, Desmond went on to complain that a standard had not yet been promulgated as of 1965 even though the FDA began its standardization process in 1959. This six-year delay, she argued, had created an interim problem for the consumer:

59. 4 October 1965, 15-16, in NARA.

60. Ibid., 101. 
a second product has usurped the grocery shelves, and in kindness one could call it peanut spread. And this is supposed to be, I believe, perfecting art or artifice, whichever way you want to look at it. ${ }^{61}$

Desmond drew a line between technology and food by reframing industry "art" as "artifice," highlighting the unnatural manipulation involved in processing peanut butter. Furthermore, she described the difficulties her group had in finding "real" peanut butter in regular supermarkets, only being able to locate it in health food stores. She critiqued this problem using President Kennedy's "right to choose" language, arguing that mainstream supermarket shoppers did not have equal access to both real peanut butter and this "second product."

However, Desmond did not argue that this "second product" should not exist, but that it should be called peanut spread, similar to the terminology used for cheese spread. ${ }^{62}$ This move helped Desmond seem reasonable and willing to compromise. She also emphasized how problematic it was that a standard had not been issued, asking one peanut butter producer whether the delay would "accustom" more consumers to lower peanut content, at which point Brennan complimented her for adding a "significant question" to the record. ${ }^{63}$ The delay issue related to a point she had made earlier in the hearing, that if the "sophisticated, informed women" of the AHEA believed that peanut butter "was still traditionally made mainly with peanuts, salt, and perhaps a little sugar," what of the "average housewife?" 64 In a later challenge to Desmond's reliance on the 1959 AHEA position, the PBMA's counsel Vincent Kleinfeld submitted a 1965 letter from the AHEA supporting an 87 percent threshold, highlighting the "new peanut butter' in preference to the old-fashioned variety." 65 The letter commended industry researchers for creating a peanut butter that spread smoothly and did not separate or dry out, or become rancid.

Though industry positions on the standard varied, most articulated views in opposition to Desmond's. The PBMA supported an 87 percent peanut threshold and more extensive list of allowable optional ingredients, but many different peanut butter producers were called to testify about their views on the standard and expressed a range of opinions, from the view that no standard was needed to the need for a standard to level the playing field between producers. One producer used its market research to argue that consumers had not asked for a peanut butter standard, but instead "indicate they want an ultra-smooth, extremely spreadable, very palatable product." ${ }^{66}$ He went on to say that while he could "live with" the 87 percent threshold,

61. Ibid., 63-64.

62. 16 December 1965,3533 , in NARA.

63. 15 December 1965,3340 , in NARA.

64. 8 November 1965,779 , in NARA.

65. 8 February 1966,6252 , in NARA.

66. 14 December 1965, 3188, in NARA. 
he felt that it would stifle future innovations to make "new and improved" peanut butter. ${ }^{67}$ While cross-examining this producer, Desmond tried to establish that consumers might be unaware of exactly how the product achieved a smoother and more spreadable consistency. ${ }^{68}$

This was just one interaction of many involving a broader debate in the hearings over what counted as a proper "survey." The term survey did not refer narrowly to questionnaires designed to elicit patterned opinions, but more broadly to any methodological activity that produced facts worthy of inclusion for the record. ${ }^{69}$ In the hearing, there were multiple "surveys" offered as evidence: FDA's summary of interested party comments; an FDA survey of the history of peanut butter based on cookbooks, patents, and technical specifications; several surveys conducted by the FDA to determine the practices and formulations of a representative set of peanut butter manufacturers of different sizes; different surveys of consumer perceptions of peanut butter conducted by industry and government agencies; and various formal and informal discussions with consumer groups and individual consumers reported by witnesses.

Though different, these surveys competed with each other as credible representations of the consumer conception of peanut butter. To compete with formal surveys, Desmond irreverently (if indirectly) critiqued them with an informal "survey" of her own. During industry's cross-examination of a government witness, the lawyer made a request to Desmond, who had brought a jar of peanut butter to the proceedings. Its label read "Coop Old-Fashioned Peanut Butter . . . Albert Lea, Minnesota."70 Counsel asked Desmond if he could use the label to question the witness. Desmond replied, "I have eaten something out of it. I am testing them all." Her informal taste-test "survey" of the peanut butters debated during the hearing reminded others that the object of debate was not abstract or lofty, but a food that can be known through sensory experience available to all-a small and playful way of asserting expertise as an ordinary peanut butter consumer. She used the subjective mode of taste to "deflate" objectivity. ${ }^{71}$

\section{"I Liked to Eat, I Wasn't a Fanatic": Developing a Mainstream Critique of Financial Conflicts of Interest}

After the hearings, Desmond recalled, "I like to eat. That's why I was excellent saying I wanted safe foods, because they could see I liked to eat, I wasn't a fanatic." Part of Desmond's strategy had been to emphasize that she was a mainstream consumer, so that she would not be construed as hav-

67. 14 December 1965, 3191, NARA.

68. 15 December 1965, 3344, in NARA.

69. Sarah Elizabeth Igo, The Averaged American.

70. 7 December 1965, 2622-23, in NARA.

71. Steven Shapin, “The Sciences of Subjectivity," 172. 
ing a fanatical viewpoint. Representing herself as an ordinary consumer was an important strategy, because industry counsel would try to discredit her as fringe. She said, "They had hoped I'd be a nut and come on and say, 'these things will hurt you.' But I didn't. I didn't play into their way at all."72

Desmond's remarks demonstrate the importance of other social movements in shaping her rhetorical strategies in the hearing, particularly the environmental and countercultural food movements. Her advocacy had originally been driven by her husband's cancer, and concern about pesticide residues as a possible cause. Rachel Carson had given a speech to the Federation of Homemakers in 1963, demonstrating that environmental issues were important to the group's agenda. ${ }^{73}$ Yet Desmond carefully navigated the relationship between the peanut butter standard and the rhetoric of the environmental and countercultural food movements. She instead used a home protectionist argument about the need for increased precaution around the introduction of chemicals into the food supply. She also aligned herself with more credible experts and distanced herself from less credible ones. Because the peanut butter standard did not involve a clear health threat, Desmond had to make a circumscribed and general argument about chemical risk that was always vulnerable to being seen as irrelevant.

During her testimony, in addition to mentioning her husband's bladder cancer, Desmond cited a study she had heard about in the color additives hearing. She mentioned that a scientist had made an important methodological critique of animal studies of color additives, that they might not be representative of humans. Given as yet unknown risks, combined with the fact that peanut butter was a food consumed primarily by children and the elderly, Desmond made a "plea" for peanut butter to be kept "free" from additives, asking Brennan, "have I given you some feeling of the depth of what I have to say?" She combined scientific evidence with emotional rhetoric to ask that the agency use "caution instead of regrettable hindsight" in its regulation of the use of chemicals in the food supply. ${ }^{74}$

Even though it seemed that many of Desmond's arguments about health risks from chemicals in foods aligned with another consumer representative, Theron Randolph, Desmond navigated her interactions with him carefully. Randolph, a physician and co-founder of the field of clinical ecology, came to the peanut butter hearing to discuss the problem of food allergies in relation to a growing "toxic environment." 75 Before Randolph testified, oil chemists from the industry and the FDA had established with their extensive testimony that hydrogenation made source oils chemically

72. Desmond, as quoted in Sugarman, "Veteran of the Peanut Butter War," D4.

73. Sarah Thomas, "A Call to Action," 194.

74. 8 February $1966,6177-80$, in NARA.

75. 17 February 1966, in NARA. On Randolph, see Michelle Murphy, "The 'Elsewhere within Here' and Environmental Illness.” On allergies, see Gregg Mitman, Breathing Space. 
JANUARY

2016

VOL. 57 equivalent, so the allergy issue was deemed irrelevant to the peanut butter standard. ${ }^{76}$ After Randolph's testimony, industry counsel cross-examined him at length to discredit his expertise and portray him as fringe. During Desmond's brief cross-examination of Randolph, she sought his opinion on the peanut butter standard as a consumer, not as an expert. Later, Desmond called her own witness up to testify, Wilhelm Hueper, who had served as the first head of the Section on Environmental Cancer at the National Cancer Institute. ${ }^{77}$ A Federation newsletter emphasized to its members that "Federation officers speak as concerned citizens but quote only recognized scientists to support their views."78 Her strategic alignment with credentialed experts demonstrates how carefully Desmond sought to be accepted as well-informed.

Desmond had her most acrimonious exchanges in the hearing with expert Frederick Stare, founder and head of the Department of Nutrition at the Harvard School of Public Health. Stare, one of the most prominent nutritionists in America, was the editor of Nutrition Reviews, a journal published by the food industry-supported organization Nutrition Foundation (NF), and author of a national syndicated column on food and health, where he warned readers about the dangers of nutritional quackery and promoted the use of safe chemicals to improve the food supply.

In the peanut butter hearings, the gist of Stare's testimony was that, from a nutritional standpoint, as long as a peanut butter contained a "substantial” amount of peanuts, it did not matter whether it was 97 or 75 percent. ${ }^{79}$ During his testimony, Stare denigrated old-fashioned peanut butter in a "not polite" description of his childhood memory of a manual peanutbutter machine in the town's grocery store, comparing the look of the food to a "dog defecating." 80 The Federation's newsletter account of the hearing said of this moment, "Dr. Stare at one time was so crude in his description of a process that our members gasped in shock and disappointment."

Since Stare had not been polite, Desmond would be more pointed. Her cross-examination of Stare questioned his testimony in previous FDA hearings, in which he had recommended that the agency use its funds to "wipe out ... or eliminate 'Food Faddism."” Desmond argued that doing so would "cripple their [FDA's] work of protecting the people, health-wise, from the inspections for pesticide residues, residues from factories, plants, restaurants." 82 "Food faddism" was one of several frames used to derogate

76. On the history of hydrogenated oil, see David Schleifer, "The Perfect Solution."

77. On Hueper, see Christopher Sellers, "Discovering Environmental Cancer."

78. "A Brief History [Federation of Homemakers]," 5 March 1979, in WSU.

79. 4 January 1966, 4022, in NARA.

80. 4 January 1966, 4011, in NARA.

81. Federation of Homemakers, "A Capsule Account of FDA's Peanut Butter Hearing," Box 4, in NARA.

82. 4 January 1966, 4068, in NARA. 
the countercultural food movement of the 1960s-70s ${ }^{83}$ Earlier in the hearing, industry counsel had tried to connect Desmond to a known "food faddist," Carleton Fredericks, because he had mentioned her on his radio show and she had written to thank him. Using her social identity as a shield, Desmond argued that she had no connection to him beyond this one-time exchange, and that she routinely wrote thank-you notes to all of her correspondents as a courtesy.

Before the late 1960s, to publicly charge respected scientists with financial conflicts of interest was "unheard of." Yet Desmond pursued a fairly aggressive line of questioning to try to reveal the dense thicket of organizational and financial connections between individuals and groups inside and outside of the room, an approach in line with Nader's later critiques of regulatory capture. Desmond asked Stare to clarify his relationship to the NF, and how exactly he was connected to industry counsel, the Food Law Institute (FLI), the Grocery Manufacturers Association, and the Pharmaceutical Manufacturers Association. Austern objected to Desmond's line of questioning, saying, "I am afraid the lady, if I may rise to this, is confused."

Desmond curtly replied, "No." She pointed out that one of the connections had been "established" at a 1964 symposium she attended-Charles Wesley Dunn, the president of the FLI, helped to set up the NF, as well as the FLI. Austern worked with Dunn to set up the FLI. Austern argued that he only worked with Dunn in regard to the FLI, and was not aware of Dunn's association with the NF or other groups. Desmond's line of questioning led industry counsel to strenuously object to her "continued line of argumentative discussion" and making of irrelevant "speeches" which industry counsel argued could be used as evidence in the record. ${ }^{85}$ Though Desmond tried to keep asking about the funds the food manufacturing industry spent to combat food faddism, Brennan interjected, saying, "Excuse me, Mrs. Desmond, but could we get back more to peanut butter? I think we are getting a little afield." Desmond replied, "Yes, sir," and shifted to cross-examining Stare about peanut butter.

A 1971 Prevention magazine article profiled Desmond's cross-examination of Stare in a section called, "How to Jab an 'Expert," elevating her to folk hero status for her work to

challenge the food industry's penchant for moulding the public taste for processed food through the use of chemistry, clever advertising, and widespread distribution that displaces other brands from the food shelves of the markets of the country. ${ }^{86}$

83. Warren James Belasco, Appetite for Change, 158.

84. Harvey Levenstein, Paradox of Plenty, 189-90; 4 January 1966, 4068, in NARA.

85. 4 January 1966, 4062-75, in NARA.

86. "Peanut Butter Grandma, the Terror of Washington," 1971, Prevention, Box 2, Folder 18, in Delaney Papers. 
JANUARY

2016

VOL. 57

The article ended its profile of Desmond by asking its readers to "toast the peanut butter grandma who spits in the corporate eye." This folksy celebration of Desmond's consumer representation work heralded the more aggressive tactics Desmond would adopt after the hearing, but obscures the strategic way Desmond took care to establish her credibility as a wellinformed housewife during the hearings, to develop a mainstream critique of corporate influence on the regulatory process.

\section{A Legal Activist}

The hearings ended in 1966, but the final peanut butter standard of identity was not published in the Federal Register until 1971, which the Prevention piece commemorated. The peanut butter industry challenged the standard in the courts, but a federal court of appeals judge upheld the standard, which was finalized at a 90 percent mandatory peanut threshold. However, the standard-of-identity mechanism as a whole was in trouble. Some legal scholars critiqued the FDA's food standardization program as "costly," and an "overreaction" to the issue of reformulating traditional foods. ${ }^{87}$ Others concurred with the FDA's assessment that the trial-type structure of the hearings was problematic and that industry groups could use this formal mechanism to delay standards. ${ }^{88}$ One administrative law scholar called the peanut butter hearing a "quagmire," and the FDA tried to find the best regulatory strategy for reforming the standard-of-identity approach. ${ }^{89}$

Junod argues that the FDA eventually adopted a strategy to pursue nutrition-based labeling in lieu of formal identity standards, so as to be more flexible and adapt to industry innovations in a rapidly changing food environment. ${ }^{90}$ Historian Xaq Frohlich interprets this shift as a way to "embed notions about personal responsibility for health into the ways that food was designed, marketed, and consumed." "I I argue that this shift also removed the standard-of-identity hearing as a space for consumers to participate directly in standards development.

Before and during the peanut butter hearings, the Federation had aligned itself with the FDA, balancing its pressure on the agency to protect consumers with supportive lobbying, asking Congress to increase the agency's funding. However, after the hearings, the Federation adopted a more adversarial, litigious position. One of the Federation's newsletters indicated that Desmond felt bullied during the hearings, saying, "we could hear words such as perjury in stage whispers and jail sentences . . . an

87. Merrill and Collier, Like Mother Used to Make, 562.

88. Gary Laden, "FDA Rule-Making Hearings."

89. Ibid.

90. Junod, “The Rise and Fall of Federal Food Standards in the United States," 47.

91. Xaq Frohlich, “Accounting for Taste,” 745. 
attempt to intimidate us." 92 Perhaps this acrimonious experience with industry counsel pushed the Federation to the more antagonistic stance it adopted in the 1970s, affiliating with Ralph Nader's Raiders to take federal agencies to court.

In 1971 and 1972, the Federation sued the U.S. Department of Agriculture (USDA), arguing that the agency violated the Wholesome Meat Act by allowing frankfurters labeled as "all meat" to contain up to 15 percent nonmeat ingredients. ${ }^{93}$ The court sided with the Federation, declaring that the USDA label was misleading to ordinary consumers. The basis for the court's decision was its use of the legal "ordinary meaning" test, which helped the court determine that common consumer understanding of the word "all" in front of the word "meat" indicated that the substance would be "totally and entirely meat." The Federation next sued the FDA in 1976, arguing that the agency's promulgated rule for the definition of an "imitation" food violated the FDCA, and was arbitrary and capricious. The FDA's definition of an "imitation" food was one that "is a substitute for and resembles another food but is nutritionally inferior to that food." The Federation complained that this definition of imitation conflicted with "the understanding of ordinary English speech," where consumer evaluation of "texture, smell, taste, appearance, manufacture, packaging and marketing all contribute to a determination of whether the food in question must be labeled an imitation." 94

Unlike the USDA frankfurter suits, the court sided with the FDA in the imitation food case. The judgment clarified that the Federation's major complaint was that the FDA had moved away from the standard-of-identity mechanism. The court did not rely on the ordinary-meaning test to construct its judgment. It saw the agency's definition of imitation as "equally reasonable," or in fact superior to ordinary meaning, because the FDA's definition would encourage producers to manufacture more nutritious products and better inform consumers to "exercise a knowledgeable choice" in the foods they consumed. While Desmond had earlier invoked the consumer's right to choose and be informed to defend standardized foods, the court's decision demonstrates how choice and information came to support the use of more technologies in the manufacture of foods, with a particular emphasis on nutrition-based labeling as a regulatory panacea to the problem of lack of information to consumers.

92. Federation of Homemakers, "A Capsule Account of FDA's Peanut Butter Hearing," Box 4, in NARA.

93. Federation of Homemakers v. Hardin, 328 F. Supp. 181 (DC 1971); Wholesome Meat Act, 21 U.S.C. $\$ 601$; Federation of Homemakers v. Butz, 466 F.2d 462 (DC Cir. 1972).

94. Federation of Homemakers v. Schmidt, 539 F.2d 740 (DC Cir.1976). 


\section{Conclusion}

In 1979, the Federation's officers wrote a brief twenty-year history of their organization, which they sent out in their quarterly newsletter. ${ }^{95}$ They informed their members about their ongoing work in a broad range of

JANUARY

2016

VOL. 57 issues, such as antibiotic use in feeds and caffeinated drinks. They cited the peanut butter standard and frankfurter labeling as particular accomplishments. They also stated the Federation had become a more "representative group," now including members of the "opposite sex," while the early membership had been all "feminine." Yet despite this claim, the group's homemaker identity likely limited expansion of its membership. In 1985, Desmond expressed "regret" that the Federation had not "gotten more attention over the years." 96

Early in her career, Desmond borrowed strategies from long-standing techniques of consumer activism: grassroots organizing, a mix of moral and gendered rhetoric from women's groups and home economists, and supporting regulatory reforms. As she began to engage more heavily in the peanut butter standard of identity, she began to pursue more novel strategies. While consumers did participate in the making of regulatory standards by submitting comments and observing and testifying at hearings, by negotiating such an active role in the peanut butter proceedings, Desmond tried to make more room in standards development for more direct consumer participation.

Yet in enacting this novel active role, Desmond still relied heavily on her gendered and aged social identity in her rhetoric and interactions with experts. To construct her argument that peanut butter was a "simple" food that should not be "made complicated," she aligned her grandmotherly identity with her preference for "old-fashioned" peanut butter. To compete with formal marketing surveys, she irreverently contributed her own tastetest of peanut butters as evidence. When interacting with experts, Desmond used her social identity to portray herself as a mainstream consumer, so that she would not be discredited as a fringe member of the counterculture or environmental movements. That said, Desmond did aggressively question experts about their financial conflicts of interest, a tactic that would not become more common until the late 1960s. Her interest in corporate funding of research, as well as the fact that she had some hostile exchanges with technical experts and industry counsel during the hearings, helps to explain how she later adopted a more adversarial approach in taking regulatory agencies to court to protect the consumer interest in the 1970s.

Desmond's negotiation of an active role in the standard-of-identity process was a short-lived achievement. Her social identity both enabled

95. "A Brief History [Federation of Homemakers]," 5 March 1979, in WSU.

96. Desmond, as quoted in Sugarman, "Veteran of the Peanut Butter War," D4. 
and constrained her consumer activism. Ultimately, her homemaker consumer identity did not remain as resonant in light of the changes occurring during the third-wave consumer movement, such as shifting gender roles, the rise of interest-group liberalism, and the professionalization of consumer advocacy. Yet core questions her work raised are enduring ones. What constitutes a fair relationship between the government, private industry, and consumers in the development of standards? And how do even the most mundane things in our world, like peanut butter, reflect power relations and moral values?

\section{Bibliography}

\section{Archival and Oral Sources}

"A Brief History [of the Federation of Homemakers]," 5 March 1979, Wichita State University, University Libraries Special Collections \& University Archives, available at http://cdm15942.contentdm.oclc.org/ cdm/ref/collection/p15942coll11/id/1182 (WSU)

Alexander Grant, Oral History Interview conducted by Suzanne W. Junod and Robert A. Tucker, 15 January 1997, Rockville, MD, available at http://www.fda.gov/downloads/AboutFDA/WhatWeDo/History/ OralHistories/SelectedOralHistoryTranscripts/UCM264446.pdf (Grant interview)

Food and Drug Administration Records, Record Group 88, National Archives and Records Administration II, College Park, MD (NARA)

James Joseph Delaney Papers. M. E. Grenander Department of Special Collections and Archives, University at Albany, State University of New York, 1950-1978 (Delaney Papers)

Winton B. Rankin, Oral History Interview conducted by James Harvey Young and Robert Porter, 30 September 1980, Zebulon, NC, available at http://www.fda.gov/downloads/AboutFDA/WhatWeDo/History/ OralHistories/SelectedOralHistoryTranscripts/UCM265893.pdf (Rankin interview)

\section{Published Sources}

21 C.F.R. $\$ 102.23$ (Code of Federal Regulations).

21 U.S.C. $\$ 601$ (United States Code).

24 Federal Register 5391 (1959).

26 Federal Register 11209 (1961).

29 Federal Register 15173 (1964).

30 Federal Register 8626 (1968).

Associated Press, "Crunch Said Yet to Come in Battle on Peanut Butter." Palm Beach [FL] Post, 2 November 1965.

Associated Press, "Women Battle over Peanuts." Ellensburg [WA] Daily Record, 8 February 1966. 
Belasco, Warren James. Appetite for Change: How the Counterculture Took on the Food Industry. Ithaca, NY: Cornell University Press, 2007.

Bijker, Wiebe E., and Karin Bijsterveld. "Women Walking through Plans: Technology, Democracy, and Gender Identity." Technology and Culture 41, no. 3 (2000): 485-515.

JANUARY

2016

VOL. 57

Bix, Amy Sue. "Equipped for Life: Gendered Technical Training and Consumerism in Home Economics, 1920-1980." Technology and Culture 43, no. 4 (2002): 728-54.

Braatan, David. "Washington Offbeat." Reading [PA] Eagle, 4 November 1969.

Busch, Lawrence. Standards: Recipes for Reality. Cambridge, MA: MIT Press, 2011.

Carpenter, Daniel. Reputation and Power: Organizational Image and Pharmaceutical Regulation at the FDA. Princeton, NJ: Princeton University Press, 2010.

Carter, Jimmy. “The President's News Conference." Presentation at the National Association of Broadcasters Conference, Dallas, TX, 25 March 1979. Available at http://www.presidency.ucsb.edu/ws/?pid=32098.

Cohen, Lizabeth. A Consumers' Republic: The Politics of Mass Consumption in Postwar America. New York: Knopf, 2003.

Corn Products Company v. Department of Health, Education and Welfare, Food and Drug Administration, and Derby Foods, Inc. v. Food \& Drug Administration, U.S. Department of Health, Education, and Welfare, 427 F.2d 511 (3rd Cir. 1970).

De la Peña, Carolyn. Empty Pleasures: The Story of Artificial Sweeteners from Saccharin to Splenda. Chapel Hill: University of North Carolina Press, 2010.

Degnan, Frederick H. "What Is in a Name? The Legal Effect of Food Standards." Food, Drug, Cosmetic Law Journal 45 (1990): 263-72.

Dibell, Katie. "Housewives Lobby through Federation of Homemakers." The Victoria [TX] Advocate, 16 January 1966.

DuPuis, Erna Melanie. Nature's Perfect Food: How Milk Became America's Drink. New York: NYU Press, 2002.

Epstein, Steven. "The Construction of Lay Expertise: AIDS Activism and the Forging of Credibility in the Reform of Clinical Trials." Science, Technology and Human Values 20, no. 4 (1995): 408-37. . Impure Science: AIDS, Activism, and the Politics of Knowledge. Berkeley: University of California Press, 1996.

Federation of Homemakers v. Butz, 466 F.2d 462 (DC Cir. 1972).

Federation of Homemakers v. Hardin, 328 F. Supp. 181 (DC 1971).

Federation of Homemakers v. Schmidt, 539 F.2d 740 (DC Cir. 1976).

Food, Drug, and Cosmetic Act of 1938, Chapter IX, Section 401.

Frohlich, Xaq. "Accounting for Taste: Regulating Food Labeling in the 
'Affluent Society,' 1945-1995." Enterprise and Society 13, no. 4 (2012): 744-61.

Glickman, Lawrence. Buying Power: A History of Consumer Activism in America. Chicago: University of Chicago Press, 2009.

Goldstein, Carolyn M. Creating Consumers: Home Economists in Twentieth-Century America. Chapel Hill: University of North Carolina Press, 2012 .

Goodwin, Lorine Swainston. The Pure Food, Drink, and Drug Crusaders, 1879-1914. Jefferson, NC: McFarland Press, 1999.

Goulden, Joseph C. The Superlawyers: The Small and Powerful World of the Great Washington Law Firms. New York: Dell, 1973.

Hamilton, Alissa. Squeezed: What You Don't Know about Orange Juice. New Haven, CT: Yale University Press, 2009.

Haydu, Jeffrey. "Frame Brokerage in the Pure Food Movement, 18791906." Social Movement Studies 11, no. 1 (2012): 97-112.

H.R. 2139, 75th Cong., 3d Sess. 5 (1938).

Igo, Sarah Elizabeth. The Averaged American: Surveys, Citizens, and the Making of a Mass Public. Cambridge, MA: Harvard University Press, 2007.

Jacobs, Meg. Pocketbook Politics: Economic Citizenship in Twentieth-Century America. Princeton, NJ: Princeton University Press, 2005.

Junod, Suzanne. "Chemicals and Controversy: Regulating the Use of Chemicals in Foods" (Ph.D. diss., Emory University, 1994).

"The Rise and Fall of Federal Food Standards in the United States: The Case of the Peanut Butter and Jelly Sandwich." In The Food and Drug Administration, edited by Meredith A. Hickmann, 35-48. Hauppauge, NY: Nova Science Publishers, 2003.

Kegan, Esther O. “A Unique Food or an 'Imitation'?” The Business Lawyer 21 (1965): 77-87.

Kennedy, John F. "Special Message to the Congress on Protecting the Consumer Interest," 15 March 1962. Available at http://www.presidency. ucsb.edu/ws/?pid=9108.

Krampner, Jon. Creamy \& Crunchy: An Informal History of Peanut Butter, the All-American Food. New York: Columbia University Press, 2013.

Laden, Gary. "FDA Rule-Making Hearings: A Way Out of the Peanut Butter Quagmire.” George Washington Law Review 40, no. 4 (1972): 726-48.

Lampland, Martha, and Susan Leigh Star, eds. Standards and Their Stories: How Quantifying, Classifying, and Formalizing Practices Shape Everyday Life. Ithaca, NY: Cornell University Press, 2009.

Larrick, George P. “The FDA and Consumer Protection.” Food, Drug, Cosmetic Law Journal 17 (1962): 266-71.

Levenstein, Harvey. Paradox of Plenty: A Social History of Eating in Modern America. New York: Oxford University Press, 1993. 
Merrill, Richard A., and Earl M. Collier Jr. "Like Mother Used to Make: An Analysis of FDA Food Standards of Identity." Columbia Law Review 74, no. 174: 561-621.

Micheletti, Michele. "Why More Women? Issues of Gender and Political Consumerism." In Politics, Products, and Markets: Exploring Political

JANUARY

2016

VOL. 57 Consumerism Past and Present, edited by Michele Micheletti , Andreas Follesdal, and Dietlind Stolle, 245-64. New Brunswick, NJ: Transaction Press, 2003.

Mitman, Gregg. Breathing Space. New Haven, CT: Yale University Press, 2007.

Murphy, Michelle. “The 'Elsewhere Within Here' and Environmental Illness; or, How to Build Yourself a Body in a Safe Space." Configurations 8, no. 1 (2000): 87-120.

Newman, Kara. "Historical Overview: World War I." In The Oxford Companion to American Food and Drink, edited by Andrew Smith, 289-90. New York: Oxford University Press, 2007.

Parthasarathy, Shobita. "Breaking the Expertise Barrier: Understanding Activist Strategies in Science and Technology Policy Domains." Science and Public Policy 37, no. 5 (2010): 355-67.

"Peanut Butter Grandma, the Terror of Washington." Prevention, 1971, in Delaney Papers.

Pendergast, William. "Have the FDA Hearing Regulations Failed Us?" Food, Drug, Cosmetic Law Journal 23, no. 11 (1968): 524-31.

Russell, Andrew L. "Standardization in History: A Review Essay with an Eye to the Future." In The Standards Edge: Future Generation, edited by Sherrie Bolin, 247-60. Ann Arbor, MI: Sheridan Press, 2005.

Schleifer, David. "The Perfect Solution: How Trans Fats Became the Healthy Replacement for Saturated Fats." Technology and Culture 53, no. 1 (2012): 94-119.

Sellers, Christopher. "Discovering Environmental Cancer: Wilhelm Hueper, Post-World War II Epidemiology, and the Vanishing Clinician's Eye.” American Journal of Public Health 87, no. 11 (1997): 1824-35.

Shapin, Steven. "The Sciences of Subjectivity." Social Studies of Science 42, no. 2 (2012): 170-84.

Sklar, Kathryn Kish. “The Consumers' White Label Campaign of the National Consumers' League, 1898-1918." In Getting and Spending: European and American Consumer Societies in the Twentieth Century, edited by Susan Strasser, Charles McGovern, and Matthias Judt, 17-35. Cambridge: Cambridge University Press, 1998.

Smith, Andrew. Peanuts: The Illustrious History of the Goober Pea. Champaign: University of Illinois Press, 2002.

Stapleford, Thomas. “'Housewife vs. Economist': Gender, Class, and Domestic Economic Knowledge in Twentieth-Century America.” Labor: Studies in Working-Class History of the Americas 1, no. 2 (2004): 89-112. 
Stewart, Richard. "Vermont Yankee and the Evolution of Administrative Procedure." Harvard Law Review 9, no. 8 (1978): 1805-22.

Sugarman, Carole. "Veteran of the Peanut Butter War." Washington Post, 13 January 1985.

. "Housewife Battles Big Boys in Food Industry." The Bulletin, 8 May 1985.

" "Homemaker Ruth Desmond a Champion of Food Safety." Los Angeles Times, 18 July 1985.

. "The Peanut Butter Grandmother: Remembering Consumer Activist Ruth Desmond.” Washington Post, 5 October 1988.

Thomas, Sarah. "A Call to Action: Silent Spring, Public Disclosure, and the Rise of Modern Environmentalism." In Natural Protest: Essays on the History of American Environmentalism, edited by Michael Egan and Jeff Crane, 185-204. New York: Routledge, 2009.

Timmermans, Stefan, and Steven Epstein. "A World of Standards but Not a Standard World: Toward a Sociology of Standards and Standardization." Annual Review of Sociology 36, no. 1 (2010): 69-89.

Vanaver, Elissa. "The Peanut Butter Grandma." The Free Lance-Star [Fredericksburg, VA], 7 July 1977.

Wynne, Brian. "Misunderstood Misunderstanding: Social Identities and Public Uptake of Science." Public Understanding of Science 1, no. 3 (1992): 281-304. 